\title{
Examining the Impact of Perceived Service Quality Dimensions on Repurchase Intentions and Word Of Mouth: A Case from Software Industry of Pakistan
}

\author{
Abdul Samad \\ Foundation university Rawalpindi campus
}

\begin{abstract}
This study attempts to investigate the relationship between dimensions of service quality using SERVQUAL, repurchase intention and word of mouth with an emphasis on mediating effect of customer satisfaction. Reliability, tangibility, assurance, empathy, and responsiveness are the five key dimensions of service quality. Total 300 questionnaires were distributed among the clientele of software houses based in Rawalpindi, Islamabad, and Lahore out of which 290 useful questionnaires were useful. The analysis was performed using correlation, multiple regression analysis and Baron and Kenny Test. The results indicated that dimensions of service quality have a significant positive influence on repurchase intention and word of mouth, and customer satisfaction partially mediates between the dependent and independent variable.
\end{abstract}

Keywords: Service Quality, SERVQUAL, Customer Satisfaction, Repurchase intention, Word of mouth, Baron and Kenny Test.

\section{Introduction}

Delivering service with quality has been researched for a long time. It is the basic factor that differentiates between highly successful and non successful firms (Joz e Lapierre, 1996).Service quality is basically meeting the customer expectations and satisfying their needs through providing quality in the services (Wen-Tai Lai, 2011).

Service quality has no single definition (Hernon N. a., 1999). It might be the superior value judged by the customers. It can be defined as conformance to requirements of the customer (Hernon N. a., 1999). Also it may be explained as the customer expectations about the service provided that are met or exceeded. Or it may be the combination of quality and price that the company is providing to its customers (Hernon N. a., 1999).

It has been studied that satisfaction largely influences upon and has a close link with perceived service quality (Wen-Tai Lai, 2011). Customers who have a higher opinion of a perceived service quality may get more satisfaction and continue to use that service i.e. customer loyalty (repurchase intention and word of mouth) (Wen-Tai Lai, 2011).

Researchers found positive influence of satisfaction and repurchase intention of customers. Customer satisfaction is basically the perception of customers to evaluate what have been received against what was expected. Repurchase intention may be the result of customer attitude and commitment towards repurchasing a particular product. (Akbar, 2009).So repurchase intention is very important for the organization because, the cost of maintaining the old customer is less than attracting a new one and making him loyal (Euphemia F.T. Yuen, 2010). One of the ways to generate word of mouth positively is through satisfaction. Positive Word of mouth basically is informal contact and communication between the customers about the particular product or service that is being used. It may be positive or negative and affect the loyalty and satisfaction of customers. (Dwayne D. Gremler, 2001).

The main objectives of this study are to examine the influence of perceived service quality as measured by SERVQUAL on repurchase intention and word of mouth with a mediating effect of satisfaction in the software development companies of Pakistan and finally to develop some insights based on findings about software companies.

This study will be the first of its kind in the context of Pakistan's software development environment in which the customers' perception regarding the software development companies is gauged. As a developing country, Pakistan still lacks the software development standards which most of the developed countries enjoy. So, this study will be beneficial to the software development sector of Pakistan in policy making. The present study intends to fill the aforementioned gap by incorporating superior methodology and sampling techniques for better analysis and policy implications. 


\section{Literature review}

Perceived service quality has been based on the difference between value that the customer expects from a service and what he perceives as the actual case (Akbar, 2009). It may also be explained as the perception of customer about service meeting or exceeding his expectations (Akbar, 2009).

Researchers have divided perceived service quality into five main dimensions i.e. Empathy, Assurance, Reliability, Tangibility and Assurance (Parasuraman, 1988). The number of dimensions may differ in different industries. Some researchers have also changed the nature of these service quality dimensions. Service quality has a great impact on number of things, one of which is customer satisfaction (Akbar, 2009).

Customer satisfaction means comparison of whether customers have received what they were expecting or not (Armstrong, 1996). It basically measures the customers' short term positive or negative response towards services that have been received (Hernon D. A., 1999).

Positive word of mouth may be generated through satisfaction (Dwayne D. Gremler, 2001).Word of mouth is the image of the company and its services that is generated through the customers (Dwayne D. Gremler, 2001). It may influence customers regarding their decision about using a particular product or service of the company (Dwayne D. Gremler, 2001). This may help in brand switching, if positive may help a company gain new customers and if negative may be harmful to the company by losing existing customers (Maxham, 2001).

Because cost of maintaining existing loyal customers is lesser than that of attracting new customers, the repurchase intention of a customer is very important for the company. This repurchase intention is impacted upon greatly by customer satisfaction (Maxham, 2001). It is basically the will of the customer to purchase same product again and again or to purchase different products or services of the same company, due to trust that the customer has on the company (Feick, 2001).

Nowadays companies give more importance to customer satisfaction and loyalty (Akbar, 2009). According to Sureshchanndra (2003) there is a strong influence of service quality on customer satisfaction. Other researchers like (Spreng, 1996) also concluded in their study that service quality directly results in customer satisfaction.

Customer satisfaction may result in repurchase intention. Several researchers have concluded in their studies that repurchase intention and positive word of mouth may form through customer satisfaction (Anderson, 1993). So the influences of customer satisfaction on repurchase intention and word of mouth is positive and a validated one.

Researchers revealed that service quality proceeds to customer satisfaction and their satisfaction in turns results in forming customer loyalty. So, service quality may or may not be explaining customer loyalty. This has been analyzed in many studies (Akbar, 2009). Studies from Cronin(1992), indicate a weak impact of service quality on repurchase intention whereas Boulding(1993) indicate a positive relationship between the two. So the influence of service quality dimensions on customer loyalty is yet to be researched on in different manner and conditions. Based on afore mentioned points, the following hypotheses were inferred:

H1: Satisfaction has a positive influence on Repurchase intention.

H2: Satisfaction has a positive influence on Word of mouth.

H3: Reliability has a positive influence on Satisfaction.

H4: Reliability has a positive influence on Repurchase intention.

H5: Reliability has a positive influence on Word of Mouth.

H6: Tangibility has a positive influence on Satisfaction.

H7: Tangibility has a positive influence on Repurchase intention.

H8: Tangibility has a positive influence on Word of Mouth.

H9: Assurance has a positive influence on Satisfaction.

H10: Assurance has a positive influence on Repurchase intention.

H11: Assurance has a positive influence on Word of Mouth.

H12: Empathy has a positive influence on Satisfaction.

H13: Empathy has a positive influence on Repurchase intention.

H14: Empathy has a positive influence on Word of Mouth.

H15: Responsiveness has positive influence on Satisfaction.

H16: Responsiveness has positive influence on Repurchase intention.

H17: Responsiveness has positive influence on Word of Mouth.

H18: Satisfaction mediates the relationship between service quality and repurchase intention.

H19: Satisfaction mediates the relationship between service quality and word of mouth. 
Figure 1 Theoratical Framework

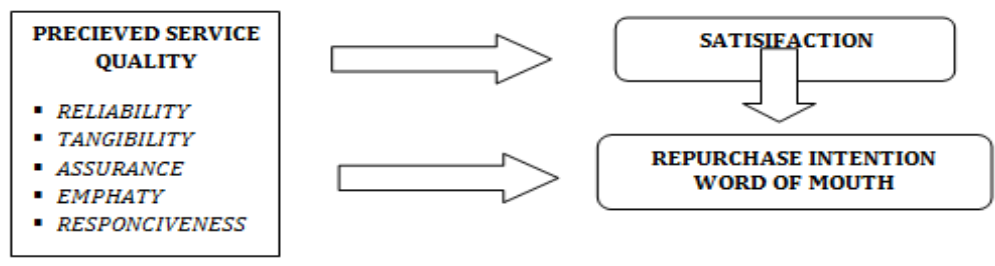

A part of this model was adopted from (Akbar, 2009) and rest is researcher's proposed model.

\section{Methodology}

The study is cross sectional and causal in nature.Data has been collected from different organizations in three cities i.e. Rawalpindi, Islamabad, and Lahore and convenient sampling method was used. A total of 300 questionnaires were distributed to different types of clients of software houses and 290 were collected back and were used for this study. The client organizations including fast food restaurants, departmental stores, readymade cloth shops, banks, bakeries, medical stores, and hospitals were approached for data collection.

A structured questionnaire comprising of four main parts i.e. Perceived Service Quality Dimensions, Satisfaction, Repurchase intention, and Word of mouth were used for collecting data. Perceived service quality was measured by using 22 item scales, an adopted version of SERVQUAL questionnaire developed by Zeithaml (1996). This scale shows the alpha reliability of 0.80 . Satisfaction has three item scale which has been used in many previous studies (Maxham, 2001), (Bitner, 1990), (Cronin Jr, 1992) (Stephens., 1987) with alpha reliability of 0.86 . Repurchase Intention (RI) has been measured on a three item scale with a reliability of 0.86 as used by (Maxham, 2001), (Ajzen., 1975). Word of Mouth (WOM) has been measured using a three item questionnaire as used previously by (Maxham, 2001), (Ross, 1992), (Jones., 1996), with a reliability of 0.87. All of the above variables have been measured using a five item Likert scale.

\section{Data analysis}

The relationships were analyzed using correlation, multiple regression analysis and Baron and Kenny mediation test.

Table4.1: Multiple regression analysis ( $*=$ Dependent variables $)$

\begin{tabular}{|c|c|c|c|c|c|c|c|c|c|}
\hline & & Satisfaction* & & & $\begin{array}{l}\text { Repurchase } \\
\text { intention* }\end{array}$ & & & $\begin{array}{l}\text { Word of } \\
\text { mouth* }\end{array}$ & \\
\hline & Beta & T-value & P-value & Beta & T-value & P-value & Beta & T-value & P-value \\
\hline Tangibility & .223 & 2.827 & .005 & .612 & 9.575 & .000 & .522 & 6.717 & .000 \\
\hline Reliability & .578 & 9.857 & .000 & .233 & 2.960 & .004 & .205 & 2.590 & .011 \\
\hline Responsiveness & .459 & 6.393 & .000 & .935 & 32.685 & .000 & .827 & 18.217 & .000 \\
\hline Assurance & .249 & 3.174 & .002 & .587 & 8.964 & .000 & .483 & 6.817 & .000 \\
\hline Empathy & .682 & 11.540 & .000 & .839 & 19.080 & .000 & .931 & 31.506 & .000 \\
\hline Satisfaction & - & - & - & .548 & 8.107 & .000 & .649 & 10.563 & .000 \\
\hline
\end{tabular}

\subsection{Baron and Kenny Test}

Table 4.2 Mediated regression (*= Dependent variable)

\begin{tabular}{|c|c|c|c|}
\hline \multicolumn{4}{|c|}{ Repurchase intention * } \\
\hline & Beta & T value & P value \\
\hline Service quality & .707 & 14.491 & .000 \\
\hline Satisfaction & .242 & 4.950 & .000 \\
\hline
\end{tabular}

Table 4.2 : Mediated regression $(*=$ Dependent variable)

\begin{tabular}{|c|c|c|c|}
\hline \multicolumn{4}{|c|}{ Word of mouth } \\
\hline & Beta & T value & P value \\
\hline Service quality & .584 & 11.826 & .000 \\
\hline Satisfaction & .396 & 8.016 & .000 \\
\hline
\end{tabular}

The first hypotheses H1 stated that Satisfaction has a positive influence on repurchase intention which was observed to be true as the regression analysis depicted that satisfaction influence repurchase intention with a strength of $54.8 \%$ as shown in table 4.1 . Our second hypotheses H2 states that Satisfaction has a positive influence on word of mouth, was also found to be true through regression analysis as satisfaction influence repurchase intention with the strength of $64.9 \%$ as depicted in table 4.1 . The hypotheses H3, H4 and H5 which stated that Reliability has a positive influence on Satisfaction, repurchase intention and word of mouth these were also found to be right as the regression analysis shows the influential strength of $57.8 \%, 23.3 \%$ and $20.5 \%$ 
respectively as shown in table 4.1. The next hypotheses $\mathrm{H} 6, \mathrm{H} 7$ and $\mathrm{H} 8$ stated that Tangibility has a positive influence on Satisfaction, repurchase intention and word of mouth were found to be true as the table 4.1 shows the influence of $22.3 \%$., $61.2 \%$ and $52.2 \%$ respectively. The hypotheses $\mathrm{H} 9, \mathrm{H} 10$ and $\mathrm{H} 11$ stated that assurance has a positive influence on satisfaction, repurchase intention and word of mouth were also found to be true as the regression analysis depict in table 4.1 the influence strengths are $24.9 \%, 58.7 \%$ and $48.3 \%$ respectively .H12, H13, H14 of the study stated that empathy has a positive influence on satisfaction, repurchase intention and word of mouth these hypotheses were found to be true as the influences shown in table 4.1 are $68.2 \%$, 83.9\% and $93.1 \%$ respectively. The $\mathrm{H} 15, \mathrm{H} 16$ and $\mathrm{H} 17$ states that responsiveness has positive influence on satisfaction, repurchase intention and word of mouth these three were found to be true as the percentage of influence were $45.9 \%, 93.5 \%$ and $82.7 \%$ as shown in table 4.1.These results were found in line with Maxham (2001), Yuen (2010), Gordon and Terrence (2000), Lars, Anne and Kai (2010) and Kyle, theodorakis, Karageorgiou, Lafazani (2010).

Baron and Kenny method was used for testing mediation after fulfilling the three conditions of this tests implementation and for this testing the five service quality dimensions were gauged in same variable with name of Service quality .The hypotheses H18 was that Satisfaction mediates the relationship between service quality and repurchase intention. Outcome indicated that this hypothesis was true as shown in table 4.2. The same Baron and Kenny test was run for H19 i.e. Satisfaction mediates the relationship between service quality and word of mouth and it was found that this hypothesis was also found true as table 4.3 depicted. The role of mediator i.e. satisfaction was found to be partial in nature. These results were in line with (Akbar, 2009)(Kim, 2011)

\section{Conclusion}

- The relationship between perceived services quality, repurchase intention and word of mouth was found to be a significantly positive one.

- The results of this study also indicate that all the service quality indicators including Reliability, Tangibility, Assurance, Empathy, and Responsiveness were statistically significant in estimation and have a positive impact on repurchase intention and positive word of mouth.

- Satisfaction level of customers plays a partial mediating role between the two variables.

This study has far reaching implications for both domestic and foreign managers working in different software companies. The associations among perceived service quality, satisfaction, and, repurchase intention and word of mouth can be used to develop customer relation policies which will help the organization in developing sound image in the market. This will also help the organizations in increasing their customer base and market share. This study can also accrue indirect benefits for corporate managers. This would imply a boost in profitability by increasing customer loyalty through implementing effective customer satisfaction policies.

\section{References}

[1] Ajzen., F. \&. (1975). Belief, attitude, intention and behavior; An introduction to theory and research reading. Addison Wesley .

[2] Akbar, P. (2009). IMPACT OF SERVICE QUALITY, TRUST, AND CUSTOMER SATISFACTION ON CUSTOMERS LOYALTY. ABAC Journal Vol. 29, No. 1. , 24-38.

[3] Anderson, E. \&. (1993). The antecedents and consequences of customer satisfaction for firms. Marketing Science 12, (1). , $125-143$.

[4] Armstrong, G. \&. (1996). Principlesof Marketing.(7th edition).

[5] Bitner, M. (1990). Evaluating service encounters:The effects of physical surroundings and employee responses. J Mark.52, 69-81.

[6] Boulding, W. K. (1993). A dynamic process model of service quality: from expectations to behavioral intentions. Journal of Marketing Research, 30 , 7-27.

[7] Cronin Jr, J. J. (1992). Measuring service quality: a reexamination and Extension. Journal of Marketing, 56. , 55-68.

[8] Dwayne D. Gremler, K. P. (2001). Generating positive word-of-mouth communication through customer-employee relationships. International Journal of Service Industry Management. Vol 12, No 1. , 44-59.

[9] Euphemia F.T. Yuen, S. S. (2010). The effect of retail service quality and product quality on customer loyalty. Database Marketing \& Customer Strategy Management Vol. 17, 3/4. , 222-240.

[10] Feick, L. \&. (2001). The impact of switching cost on the customer satisfaction-loyalty link; mobile phone service in France. Journal of Service Marketing, 15 (1). , 35-48.

[11] Hernon, D. A. (1999). Service Quality and Customer Satisfaction: An Assessment and Future Directions. the Journal of Academic Librarianship.25-1. , 9-17.

[12] Jones., H. \&. (1996). Employee performance cues in a hotel service environment: Influence on percieved service quality, value and word of mouth intentions. J Bus Res.35.

[13] Joz e Lapierre, P. F. (1996). Research on service quality evaluation: evolution and methodological issues. Journal of Retailing and Consumer Services Vol 3, No 2. , 91-98.

[14] Maxham, J. G. (2001). Service recovery's influence on consumer satisfaction, positive word-of-mouth, and purchase intentions. Journal of Business Research 54. , 11-24.

[15] Parasuraman, A. Z. (1988). SERVQUAL: a multiple-item scale for measuring consumer perceptions of service quality. Journal of Retailing, 64 (Spring). , 12-40.

[16] Ross, G. (1992). Consumer responses to service failure: Influence of procedural and interactional fairness perceptions. J Bus Res.

[17] Spreng, R. (1996). An empirical examination of a model of perceived service quality and satisfaction. Journal of Retailing, 72 (2). , 201-14. 
[18] Stephens., C. (1987). Effects of relationship marketing on satisfaction, retention and prices in life insurance companies. J Mark.(24),4 , 404-11.

[19] Sureshchanndra, G. S. (2003). The relationship between service quality and customer satisfaction - a factor specific approach. Journal of Service Marketing, 16 (4). , 363-379.

[20] Wen-Tai Lai, C.-F. C. (2011). Transport Policy 18.www.elsevier.com /locate/tranpol. Behavioral intenti ons of public transit passenger s- The roles of service quality, perceived value, satisfaction and involveme nt. , 318-325.

[21] Zeithaml, B. a. (1996). The behavioral consequences of service quality. Journal of Marketing,60. , 31-46. 